INTERNATIONAL JOURNAL OF

ECO-CULTURAL TOURISM, HOSPITALITY PLANNING

AND DEVELOPMENT

\title{
ECOTOURISM Management in Egypt with special Emphases on protected Area
}

\section{Zaghloul Muhammad Ahmad AL-SAIDI, Zakir Moussa TAMAM, Kamal Khalaf ISMAIL,}

Department of Urban Planning Engineering, College of Engineering, Al-Azhar University, Egypt

\begin{abstract}
Ecotourism in Egypt beyond conservation and sustainable tourism as is commonly understood. This paper presents the assessment on the national ecotourism strategy in Egypt, and the local community context. The study found out that the protected area are complex and it's ecotourism in Egypt. a branch of nature tourism, a segment of sustainable development, and a component of mainstream tourism. This is on top of the national-local government-civil society in policy development and management. This paper deals with strategic plan and management with local community and the development of the local communities the protected area.

Keywords

Nature, Protects, Ecotourism, Egypt
\end{abstract}

\section{Introduction}

Management and development strategy of protected area includes the development and maintain using interested - based information resources, it is very important to promote sustainable and informatics in tourism to develop the socio- cultural and the economy continue to encourage and assist the community in the..

Inform visitors the current protection and the conservation processes in the protected areas identify management actions for each protected areas and identify the management strategies, identify the causes of impacts management in response to concerns about the increase of resources and natural resources planning it is very important to ......

Develop the physical, biological and social as guidelines for management of the protected areas which includes, visual characteristics, site management, visitor management, social

Encounters and visitor impacts, development of management action plane in the protected areas covering all activities and the recourses.....

The Eco tourists who travel to the natural areas with the specific objective of studying, admiring and the enjoying the scenery, wild plants and animals and cultural sites.

It is very important to use the universal design, signs and printed media that will contribute the safety and friendly accommodation of all visitors.

The suggested management plan for protected areas; 


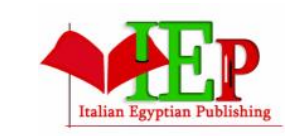

ISSN: 2735-5462

\section{INTERNATIONAL JOURNAL OF \\ ECO-CULTURAL TOURISM, HOSPITALITY PLANNING \\ AND DEVELOPMENT}

VOLUME 2, ISSUE 1, 2018, $1-20$.

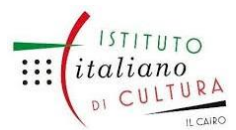

www.egyptfuture.org/ojs/

Produce a vision of conservation policy of protected areas.

Organize a database about ecosystem, visitors' activates and services.

Identify the heritage themes, resources capability and suitability, appropriate visitor activities create a site management plan includes objectives and guidelines.

Developing and marketing diversified and competitive ecotourism products

Creating conducive environment for ecotourism investments

Maximizing economic benefits for the host communities

Promoting and developing a culture of ecotourism

Strengthening institutional capacity

Developing and strengthening partnerships

Establishing mechanisms for sustainable financing

Monitoring outcomes and impacts

The ecotourism in Egypt beyond conservation and sustainable tourism as is commonly understood. This paper presents the assessment on the national ecotourism strategy in Egypt, and the local community context. The study found out that the protected area are complex and it's ecotourism in Egypt. a branch of nature tourism, a segment of sustainable development, and a component of mainstream tourism. This is on top of the national-local government-civil society in policy development and management. This paper deals with strategic plan and management with local community and the development of the local communities the protected area.

The sustainable development in ecotourism requires cultural orientation beyond the current understanding of ecotourism. It's need education and human resource development especially at the local government and community level. Concerns with political and environmental skills complemented by economic and financial goals to make ecotourism sustainable development.

\section{Results and Discussion}

Ecological systems vary in Egypt, which led to the multiplicity of areas and attractions for eco-tourism in which there are (safari trips - bird watching - camps - geological prospecting - searching for antiquities and mountaineering).

The process of planning natural reserves determines how the various resources will be distributed among the various activities by dividing the protected area into internal areas according to the capabilities, 


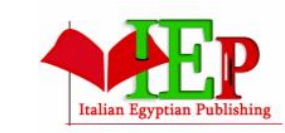

ISSN: 2735-5462

\section{INTERNATIONAL JOURNAL OF \\ ECO-CULTURAL TOURISM, HOSPITALITY PLANNING \\ AND DEVELOPMENT}

VOLUME 2, ISSUE 1, 2018, $1-20$.

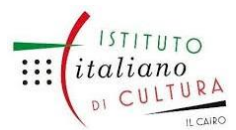

www.egyptfuture.org/ojs/

resources and characteristics of each region.

The process of dividing natural areas internally into zones must be based on a system that defines the priorities related to the objectives of establishing the natural reserve, and the proposed uses therein, and also takes into account the suitability of the activities of the visitors and their numbers with the ecosystem in each area designated for a specific activity. With higher density in sites with less environmental sensitivity, it is one of the first steps in the design of protected areas.

The sustainability of nature reserves is linked to rational investment in the field of nature conservation, considering it one of the components of the use of lands of high economic importance.

The planning process for managing the natural reserve is an endless set of monitoring and follow-up processes, and evaluating the activities that affect these natural areas, and for this the management plan requires recognition of the dynamics of ecosystems in addition to an organizational structure to implement the objectives of this long-term plan, and the management plan comes as a next step after setting policies and goals.

Recommendations:

Managing tourism activities within an environmental development plan within a timeframe that codifies methods of dealing with the environment. $\square$ Environmental awareness and environmental culture must be strengthened, the concepts and requirements of dealing with environmental affairs must be established at all levels, and the principles of sustainable development should be supported through rational environmental management, follow-up and evaluation of their implementation, and to ensure the safety of the environment, combat pollution and preserve the environmental balance within the framework of the objectives of that development at the national and international levels. Organizing the tourism and surrounding environmental development in a way that achieves environmental integration between the community and its natural environment.

Protected areas are divided into specific sectors according to location and type determinants, and each reserve is dealt with in proportion to the proposed development determinants for its private sector, for example the Red Sea region differs from the Mediterranean coast region and from the valley and Fayoum regions.

Application of sectorial and comprehensive development of reserves in Egypt and linking them to the 


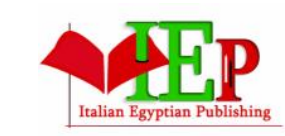

ISSN: $2735-5462$

\section{INTERNATIONAL JOURNAL OF \\ ECO-CULTURAL TOURISM, HOSPITALITY PLANNING \\ AND DEVELOPMENT}

VOLUME 2, ISSUE 1, 2018, $1-20$.

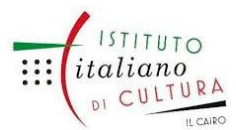

www.egyptfuture.org/ojs/

mechanism of economic development strategically to stimulate environmental and urban development and achieve positive interaction for development transactions

You must take into account the separation of uses of a quiet nature from the same fast- moving nature and not contact the automated use with the part of an important environmental nature of the reserve while trying to schedule activities in the same area throughout the day or season.

\section{References}

1- Reserves Law - No. 112 of 1983.

2-Nature reserves and biological diversity in Egypt, Assiut Journal for Environmental Studies, issue nineteen.

3-The statement of the Ministry of State for Environmental Affairs regarding the nature reserves in Egypt for the year $2004 \mathrm{AD}$.

4-Muhammad Sabri - The natural environment, its characteristics and human interaction with it - Dar Al-

Fikr Al-Arabi, 1996.

5- Ministry of Tourism, Tourism Promotion Authority, Tourism Research Journal, fourth topic, December 1102 issue.

6- Nicholas Mullionen - translated by Dr. Al-Qassas "Human Ecosystems" - Dar Al-Fikr Al-Arabi. Abdul.

7- Rahman Abdullah - The main approaches and concepts that contribute to achieving sustainable tourism development - Master's thesis,Faculty of Engineering - Cairo University 2000 AD.

8- Assem Abdel Hamid - Planning and designing protected areas in Egypt (case study of Wadi El-Rayan Reserve) - Master's degree1995 - Cairo University.

1972. Grid, philosophies, and practices principles Tourism W., R. 9-

11-Megan Epler Wood, Ecotourism Principle Practices Policies for Sustainability, UNEP 2003. 12-EL khateep - Samah Mohammed - Interrelations between Preserved Natural Areas \& Urban Environment Master 2006- Ain Shams University-P 79.

13- Richard R .Forester. (1975): planning for man and natural in national parks - Reconlling 


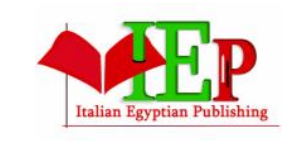

ISSN: $2735-5462$

\section{INTERNATIONAL JOURNAL OF \\ ECO-CULTURAL TOURISM, HOSPITALITY PLANNING \\ AND DEVELOPMENT}

VOLUME 2, ISSUE 1, 2018, $1-20$.

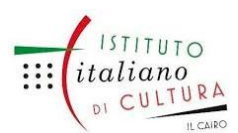

www.egyptfuture.org/ojs/

Perpetuation and use.

14- IUCN, 1993, United Nations List of National Parks and Protected Area, WCMC and CNPPA, Gland 1994.

15- Guidelines for Management Planning of Protected Areas - World Commission on Protected Areas (WCPA) - p20).

16- Egyptian Environmental Affairs Agency, Management Plan for Zaranik Protected Area

17- Ministry of state for environmental affairs Egyptian environmental affairs agency natural

conservation sector - Action Plan for implementing the convention on Biological diversity's program of work on protected areas.

18- WWF, 1992. Beyond the green horizon: a discussion paper on principles for sustainable tourism., Surrey: WWF.

19- Bricker, K. S., 2001. Ecoutourism Development in the Rural Highlands of Fiji. In: D. Harrison, ed. Tourism and the Less Developed World Case Studies. London: CABI, pp. 234-249.

20- Buckley, R., 2003. Case Studies in Ecotourism. Wallingford: CAB International.

21- Harrison, D., 2001. Tourism impacts on island environments: towards a framework in decision making. In: H. Varma, ed. Island Tourism in Asia and the Pacific. Madrid: World Tourism Organisation, pp. 65-77.

22- Buckley, R., 2003. Case Studies in Ecotourism. Wallingford: CAB International.

23- UNESCO, 2015. Galapagos Islands. [Online]

Available at: http://whc.unesco.org/en/list/1

[Accessed 1902 2015].

24- Weaver, D., 2000. Tourism and National Parks in Ecologically Vulnerable Areas. In: R. W. Butler \& S. W. Boyd, eds. Tourism and National Parks: Issues and Implications. Chichester: John Wiley \& Sons, pp. 10124. 